\title{
Sex-specific connectivity modelling for brown bear conservation in the Carpathian Mountains
}

\author{
M. Pino García-Sánchez • Sergio González-Ávila • Joaquín Solana-Gutiérrez • \\ Marius Popa • Ramon Jurj • Georgeta Ionescu • Ovidiu Ionescu • \\ Mihai Fedorca $\cdot$ Ancuta Fedorca
}

Received: 7 March 2021 / Accepted: 31 October 2021 / Published online: 19 November 2021

(C) The Author(s) 2021

\begin{abstract}
Context Romania is currently one of the bestconnected landscapes, with high-quality habitats and a high density of brown bears. However, regional development measures are needed for the nation's economic growth, and without responsible government actions, these measures pose a threat to brown bear connectivity, a vital pillar of the entire Carpathian region. Despite having important implications for the
\end{abstract}

M. Pino García-Sánchez and Ancuta Fedorca have contributed equally.

Supplementary Information The online version contains supplementary material available at https://doi.org/10.1007/ s10980-021-01367-8.

M. P. García-Sánchez · S. González-Ávila .

J. Solana-Gutiérrez

Department of Forest and Environmental Engineering and Management, MONTES (School of Forest Engineering and Natural Resources), Universidad Politécnica de Madrid (UPM), Calle José Antonio Novais 10,

28040 Madrid, Spain

M. Popa · R. Jurj · G. Ionescu · O. Ionescu •

M. Fedorca · A. Fedorca $(\bowtie)$

National Institute for Research and Development in

Forestry Marin Dracea, Closca Street 13, 500040 Brasov,

Romania

e-mail: ancutacotovelea@yahoo.com species conservation, bears sex-specific behaviour has been overlooked in connectivity assessments.

Objectives The study's main goals were to (i) develop sex-specific distribution and connectivity models, (ii) assess the movement patterns differences between females and males, and (iii) identify highquality areas to be secured for species connectivity conservation.

Methods We designed a methodological framework based on interdisciplinary approaches and modelling tools for landscape connectivity combined with novel spatial analysis. Telemetry data of sixteen bears (females and males) were utilized to predict habitat selection (MaxEnt), and circuit-theoretic approaches (Circuitscape) were applied to identify the potential

O. Ionescu - M. Fedorca · A. Fedorca

Faculty of Silviculture and Forest Engineering,

Transilvania University of Brasov, Beethoven Lane 1, 500123 Brasov, Romania 
movement corridors of both sexes and high-priority areas.

Results The obtained results provided new evidence on the uneven movement patterns and pathways used by males and females in the study region. Males' movement preferences were related to river shores and dense forest coverage areas, avoiding urban areas, while females were predicted to move across forested and open areas and were more tolerant to human-modified areas. Three high-quality areas were delineated for both sexes, and connectivity conservation efforts are needed due to the vicinity of anthropic pressures.

Conclusions This study depicts the usefulness of combining interdisciplinary approaches and provides planners, managers, and decision-makers with practical solutions to address sustainable design and management within the intervened landscapes. Using separate female and male spatial models for leading management and conservation measures, setting connectivity targets within environmental and impact assessments while adopting conservation easements could secure a safety network for biodiversity conservation in the Carpathians.

Keywords Landscape connectivity - MaxEnt . Circuit theory $\cdot$ Romania $\cdot$ Carpathian Mountains · Brown bear

\section{Introduction}

The Carpathian range is known as Europe's last remaining refuge for large carnivore species (Webster et al. 2001), such as the brown bear (Ursus arctos). The population sizes of this ursid species have experienced increasing trends in recent decades across Europe and within Romania's national boundaries, primarily thanks to protection measures implemented under EU laws (Chapron et al. 2014). Nevertheless, the development of new infrastructures, urban sprawl and land-use changes, especially those in emerging economies in Eastern Europe, such as Romania, could pose a risk to the species inhabiting the mountain range ecosystems if no proper mitigation measures are implemented. Moreover, the human footprint and the high population density of the brown bear in this area increase the conflict between the predator's behaviour and local economic activities, especially livestock farming (LIFE FOR BEAR-Project LIFE 13 NAT/ RO/001154) (http://www.forbear.icaswildlife.ro/en/).

The abovementioned human-related factors threatening biodiversity in the Carpathian region generate both landscape fragmentation and habitat losses and affect the species' movement pathways. Furthermore, rapid climate change effects threaten the home ranges of wildlife, forcing species to shift their distribution areas in search of quiet zones and suitable habitats (Walther et al. 2002; Hermes et al. 2018; Williams et al. 2020). Thus, species need suitable paths to move towards new areas with appropriate conditions, ensuring gene flow among populations (Hilty et al. 2020), especially those with large area requirements such as the brown bear (Maanen et al. 2006; Fernández et al. 2012). The deployment of a dense network of movement corridors interconnecting species occurrence sites is the most efficient method to prevent habitat fragmentation impacts derived from anthropic activity and climate change (Naidoo et al. 2018). Moreover, due to its vast spatial requirements, the brown bear may serve as an umbrella species and, therefore, as a tool for prioritizing areas with high conservation value (Roberge and Angelstam 2004; Liu et al. 2018; Fedorca et al. 2020; Williamson et al. 2020).

Generally, bears move across long distances to find food or mates. Nevertheless, the home range sizes of males and females can vary among different areas depending on the food availability and population density. Male brown bears are known to disperse over considerable distances (Swenson et al. 2000; Dahle and Swenson 2003), while females stay close to their natal areas (Zedrosser et al. 2007; Fedorca et al. 2019). Furthermore, bear movement rates differ across seasons (Lewis and Rachlow 2011; Pop et al. 2018; Zeller et al. 2019). However, among documented brown bear patterns, males increase their movements when seeking females in heat during spring and are attracted to females' home range areas (García et al. 2007).

Notably, species movements and habitat selection and the tolerance of each sex of the species to major roads and urban areas have hardly been studied as yet. Moreover, conservation planning has not considered sex-specific modelling until now, although it is a central issue in bears behaviour. We aimed to expand upon previous connectivity analyses conducted for the brown bear (Posillico et al. 2004; Mateo-Sánchez et al. 2015a, b; Ziółkowska et al. 2016), specifically by 
modelling the most likely movement routes of this species at the regional scale in the central Carpathian territory in Romania. This approach integrates different lines of action, scientific research based on empirical data and validated features on bear population ecology, and promotion of practical conservation measures for the species focused on sex-specific brown bear habitat selection. We hypothesized that these sex-biased preferences would ultimately be transferred to connectivity models and serve as an essential tool for designing distinct and specific management actions.

The main goals of this study were to (i) develop sex-specific distribution models and derive landscape resistance from the results; (ii) model and map connectivity; (iii) assess sex-based movement patterns for consideration in management and spatial planning, and (iv) identify high-quality areas to be secured for species connectivity conservation.

\section{Materials and methods}

The methodology applied to achieve the study goals consisted of the following steps: (a) define the study area, (b) filter the telemetry GPS data and select species' presences, linked to exploratory movements and environmental covariates, (c) model habitat suitability based on MaxEnt and derive sex-specific resistance surfaces, (d) model connectivity using Circuitscape and implement a 'wall-to-wall' approach, (e) quantify sex-specific similarities in the obtained models, and finally (f) develop a novel procedure for identifying high-priority areas in the main movement pathways potentially used for dispersal by the species (Fig. 1).

Study area

The study area is located in the southern Carpathian Mountains, encompassing Brasov, Prahova, Arges, Covasna, Dambovita and Buzau counties. The spatial extent of the study area covered $5.756,33 \mathrm{~km}^{2}$ and was delimited by a $50-\mathrm{km}$ buffer encompassing all bear GPS datasets using ArcGIS (see Fig. 2). This area harbours one of the highest densities among the brown bear home range areas on the continent, locally reaching over 20 bears $/ 100 \mathrm{~km}^{2}$ (Jerina et al. 2013). In particular, the species population trend is slightly increasing in some studied regions, such as Covasna and Brasov (Cazacu et al. 2014). The study area is characterized by moderate elevations and moderate to steep slopes in a continental temperate climate zone. This climate is marked by large temperature shifts that lead to different temperate ecosystem vegetation coverages types. Large and continuous forest patches cover $50 \%$ of the area and alternate with smaller patches of transitional woodland shrubs, moors, heathlands and natural grasslands. Bare rock surfaces can be found in open spaces with little or no vegetation at higher elevations. The rest of the area is covered by intensive human uses, such as agricultural land uses $(25 \%)$ in flat landscapes and urban artificial surfaces (5\%). Most of the European and national road sections crossing the study area are single roads with two or three lanes, which are not very restrictive but are very crowded $(30,000$ vehicles/ $24 \mathrm{~h}$ during summer in Busteni). In addition, the study area presents key relevant sites located on one of the major axes of the Transcarpathian wildlife ecological network, which are protected under European or national conservation policies.

\section{Brown bear presence data}

Telemetry data from GPS radio collars were gathered from different research projects carried out by the Wildlife Department from INCDS Marin Dracea (Life for Bear, Life Safe Crossing, BEAR around Brasov, Nucleu Programme). The dataset included 63,124 records from 28 brown bear individuals collected over nine years from 2006 to 2018 . The records included male and female bears and referred to a single bear population (Fedorca et al. 2019). The tracking period for a single bear varied from 1 to 19 months, and the time intervals between records ranged from $30 \mathrm{~min}$ to $4 \mathrm{~h}$, depending on each collar type. The heterogeneity of the dataset was not sufficient to produce a reliable analysis based on path or step selection functions (Zeller et al. 2012). Thus, we filtered the whole dataset and obtained point locations as presence data to apply MaxEnt.

Using telemetry data in species distribution models (SDMs), such as MaxEnt, can cause severe spatial biases in the collected occurrence data due to the overrepresentation of some regions within a study area (Kramer-Schadt et al. 2013) (e.g., resting sites). Thus, to avoid temporal and spatial autocorrelations, we 


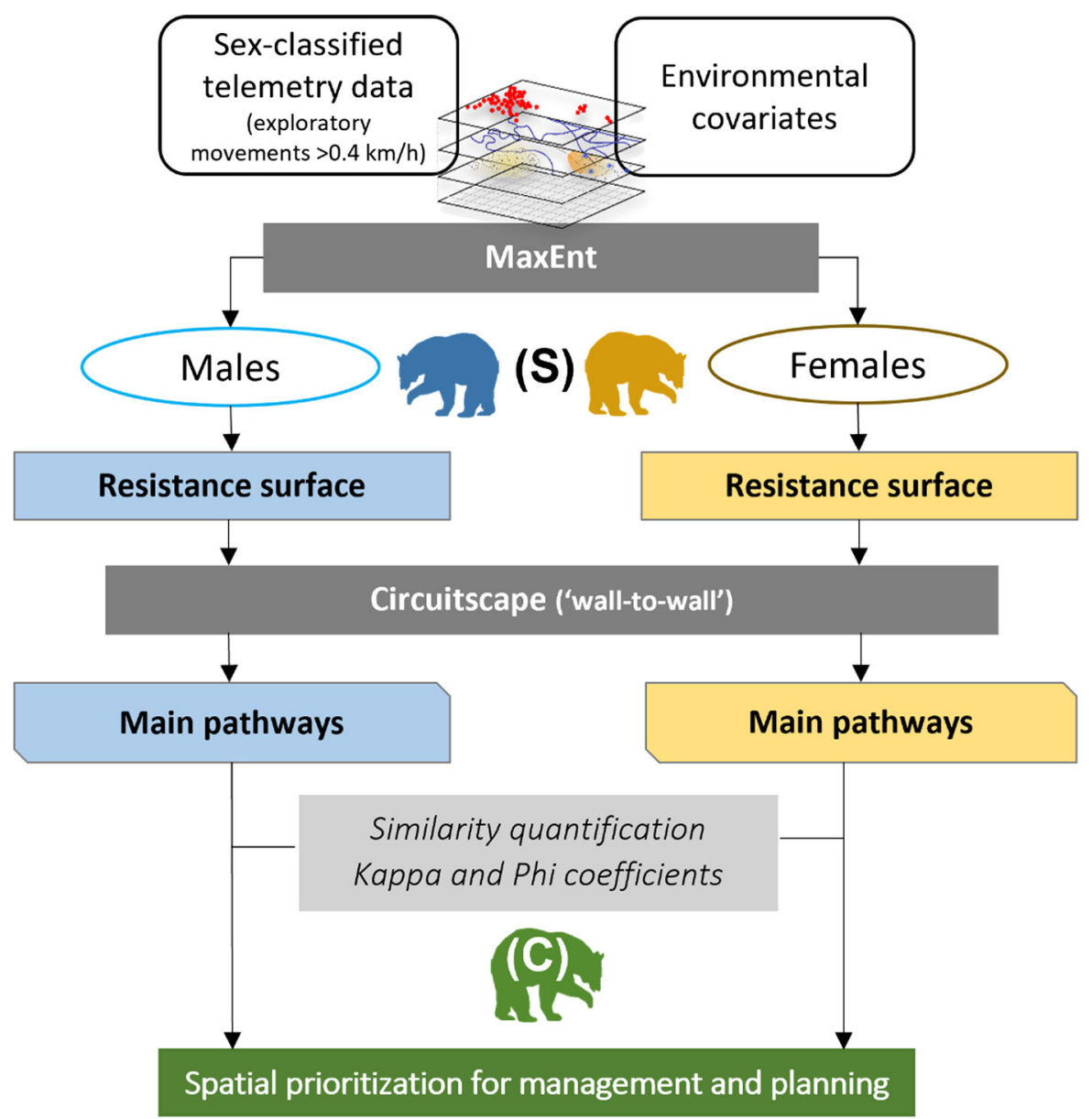

Fig. 1 Scheme of the designed methodological framework: (S) Sex-specific modelling applied by MaxEnt, species telemetry data and environmental covariates collection and processing; transformation into resistance surfaces; connectivity modelling

reduced the number of radio-tracked GPS locations by systematic sampling (Everitt 2006; Fourcade et al. 2014; Gantchoff et al. 2019). To ensure an equal sampling density over the entire tracking period, we filtered the initial dataset by keeping three random location records per specimen and per monitored day; then, we resampled to a 300-m grid distance (Mikolás et al. 2016). Consecutively, we kept one record within a 500-m radius (Ziółkowska et al. 2016).

Additionally, this resampled dataset was further filtered to select the point locations corresponding to exploratory movements, discarding those from the daily activities and focusing on long-range and dispersal movements. The disparate time interval of the GPS data impeded the use of a hidden Markov model (HMM) to discriminate these movement types applying Circuitscape; and measuring similarities among models. (C) Spatial prioritisation and planning based on common results (females and males)

with sufficient data, so we based our filtering procedure on the inspection of the frequency distribution of daily movement speeds (Shepard et al. 2013; Karelus et al. 2017). Considering the original 63,124 records, the mean speeds estimated for female and male daily movements were 0.15 and $0.18 \mathrm{~km} / \mathrm{h}$, respectively. However, we set the speed threshold to select exploratory movements at $0.4 \mathrm{~km} / \mathrm{h}$, which was more than twice the mean speed and corresponded to the 80th percentile of the daily speed route distribution, to ensure that we retained the longest and least-frequent movement events (Falcucci et al. 2009; Maiorano et al. 2017). Finally, we kept 178 bear locations recorded by GPS (78 records for nine females, mostly with cubs; 100 records for seven males, mostly young) (Supplementary Material, Table S1, and Fig. 2). 


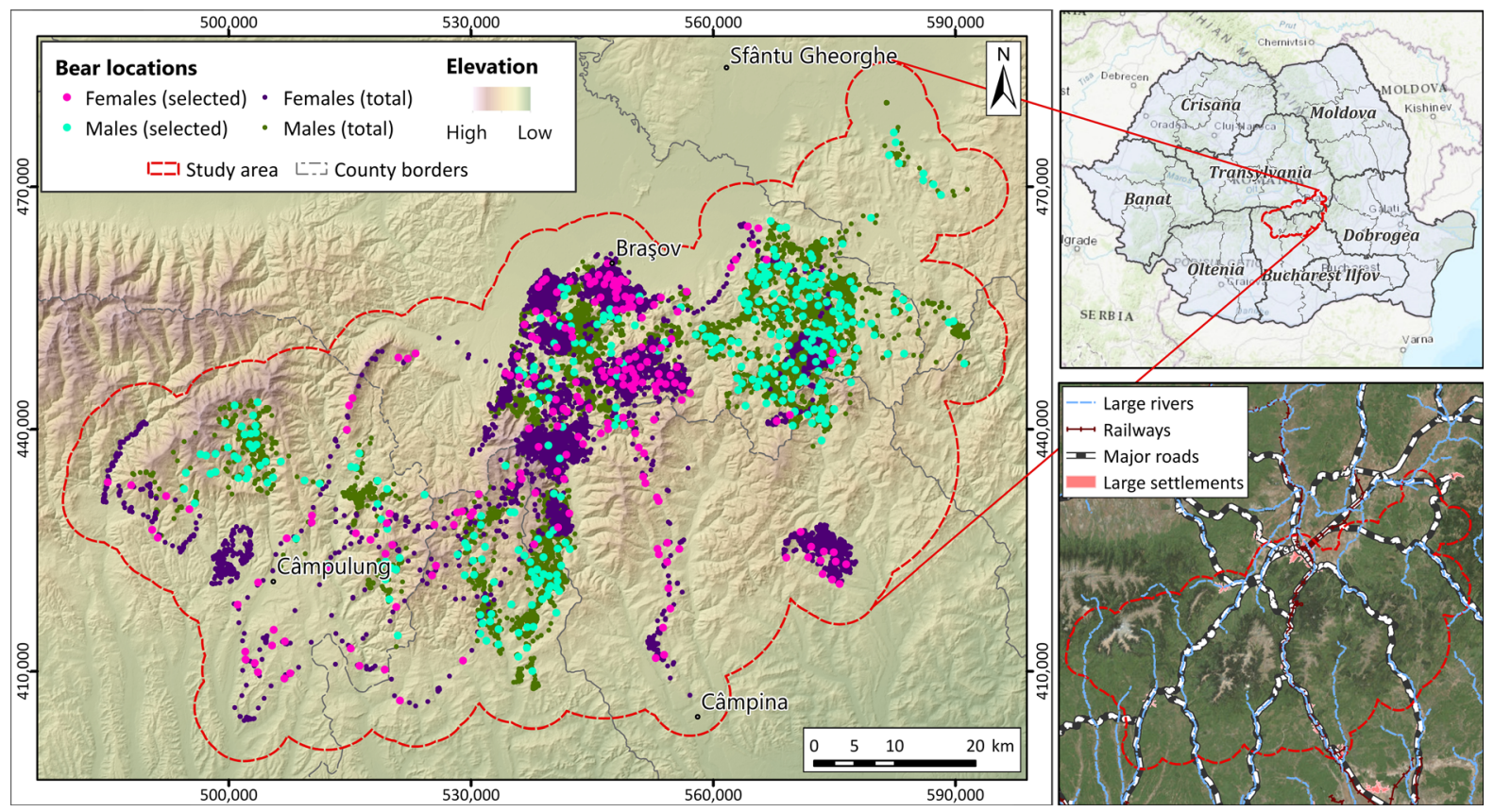

Fig. 2 Study area and GPS locations for female and male brown bears

Environmental covariates

To develop our MaxEnt models, we initially selected 25 environmental covariates documented for brown bears (Ziółkowska et al. 2016; Cristescu et al. 2019; Fedorca et al. 2020) (Supplementary Material, Table S2). Elevation, aspect and land cover are strongly related to food availability and sheltering areas, the main habitat selection factors in all seasons, especially during hyperphagia (Pop et al. 2018). To represent human-dominated landscapes, we considered major anthropogenic disturbances located close to bear areas in terms of their distances to settlements and linear infrastructures. It is worth noting that dispersal may be less constrained by landscape conditions than by habitat use in vital domains (Mateo-Sánchez et al. 2015a, b). Hence, this previous selection noted differences in individuals' tolerances to disturbances among female and male dispersal activities. Additionally, for covariates suspected to be correlated with landscape species perception (i.e., topography and vegetation heterogeneity), five related variables were considered by their focal means within circular moving windows with $1-\mathrm{km}$ radii (Salvatori 2004; Mateo Sánchez et al. 2014; Ziółkowska et al. 2016; Ashrafzadeh et al. 2020).
All the covariates were prepared for a background area of $30,255.46 \mathrm{~km}^{2}$, resulting from a $50-\mathrm{km}$ buffer surrounding the original study area $\left(5756.33 \mathrm{~km}^{2}\right)$, in accordance with the Koen et al. (2014). In addition, all the variables were resampled at $250-\mathrm{m}$ cell size, the best possible spatial resolution given the analysis extent and original resolutions of the variables (see Syfert et al. 2013). All analyses of spatial data were performed using ArcGIS v.10.6 software.

\section{Species distribution modelling}

We used MaxEnt (Phillips et al. 2006; Elith et al. 2011; D'Elia et al. 2019) as an SDM approach to predict and map bear movement preferences by means of presence probabilities (generally known as habitat suitability models) (Elith et al. 2006; Dudík et al. 2007; Phillips and Dudík 2008; Millar and BlouinDemers 2012; Romportl et al. 2013). The approach applied by MaxEnt is known as a point selection function (PSF), sensu Zeller et al. (2012), and seeks to find the combination of environmental parameters that best explains the distribution of the detected data based on presence-only or presence-absence points. The selected MaxEnt settings included a maximum of 90,000 random points as background data, a 
convergence threshold of 0.00001 , the default regularization settings (1), a cross-validate replicate run type (random seed checked) with a maximum number of 2500 iterations, and linear, quadratic and hinge features (Merow et al. 2013; Glover-Kapfer 2018). We selected the logistic output to run the models since the values can be interpreted as the presence probability to provide clearer results (Elith et al. 2011; Merow et al. 2013).

We ran the first models with a total of 25 covariates and 178 bear locations. Then, we identified variable pairs with a Pearson correlation coefficient greater than or equal to 0.7 (Dormann et al. 2007) and excluded the least powerful variables from each pair, according to the jack-knife test results given by MaxEnt. Identical covariates were utilized to develop male and female bear models. To discard the nonsignificant features for modelling, we analysed anomalies and low-variability rates from the response curves and the jack-knife test results. Finally, only nine non-correlated covariates were selected and combined to build definite habitat suitability models (Table 1).

The predictive power of the models was tested using MaxEnt $k$-fold cross-validation based on 25 replicate random partitions of the presence and pseudo-absence data (Millar and Blouin-Demers 2012). Then, we used the AUC given by MaxEnt (Manel et al. 2001; Phillips et al. 2006, 2009; Kabir et al. 2017) to assess each model's ability to discriminate where the species finds suitable habitat conditions in the study area. We built five definite models for both females and males, using nine to five covariates with the highest predictive accuracy and selected the best predictive fit performance (refer to Supplementary Material, Table S3 to check the contribution rates of the selected covariates for each model performance).

\section{Modelling resistance surfaces}

We derived sex-specific resistance surfaces from the SDMs. Resistance surfaces are the most common method used to define permeability across landscapes (Beier et al. 2008; Cushman and Lewis 2010; Zeller et al. 2018). These maps represent landscape permeability in terms of the local cost of movement for a given species through a particular environment due to behavioural and physiological factors such as aversion, energy expenditure, or mortality risk (Zeller et al. 2012). According to this study approach, our modelling results reflect how the environment affects bear movements outside their current home ranges. Assuming that higher occurrence probabilities infer that the landscape features selected for movement denote higher suitability values, following Keeley et al. (2017), we applied a negative exponential function to transform the suitability values into resistance values (Duflot et al. 2018; Dai et al. 2019):

$R=e^{\frac{\ln (0.001)}{\text { threshold }} * H S I} * 1000$

where the HSI is related to the bears' occurrence probability obtained from MaxEnt modelling and the threshold value, which is considered to transform probability to presence and absence data (Liu et al. 2005), defines the minimum suitability for the species occurrence.

According to the alternative approaches of Liu et al. (2005) to set the cut-off value, we considered the average predicted suitability on the occurrence data locations, coinciding with the stricter criterion, to simulate the worst-case scenario (Supplementary Material, Table S4). The resulting resistance surface values ranged from 0 to 1000 , where 0 indicates the most favourable areas for bears to move through and 1000 indicates zones with the most constrained movement. Furthermore, the selected HSI values were greater than 0.5 , considering the minimum probability of bear presence in the logistic models (Posillico et al. 2004; Peters et al. 2015).

\section{Connectivity modelling using Circuitscape}

Brown bear landscape connectivity was modelled by applying circuit theory in Circuitscape 4.0 (McRae et al. 2008, 2016). Circuitscape is a connectivity analysis software that estimates the probability, utilizing the current density, of a random walker passing through each cell as it moves from a previously defined source point and to a destination point (McRae et al. 2008; Diniz et al. 2020). This approach considers all alternative pathways connecting these points, representing an interesting characteristic when generally analysing movement routes, as is our case.

In Circuitscape analyses, the source and destination points usually correspond to known habitat areas of the focal species, which can bias current density 
Table 1 Non-correlated and selected covariates considered in the final brown bear habitat models

\begin{tabular}{|c|c|c|c|c|}
\hline $\begin{array}{l}\text { Variable } \\
\text { category }\end{array}$ & $\begin{array}{l}\text { Environmental features description (scale } \\
\text { in } \mathrm{km} \text { ) }\end{array}$ & Code & Unit & Data source (raster resolution) \\
\hline Topographic & Mean slope (1) & FM SLOPE & $\%$ & DEM25 (25 m) \\
\hline \multirow[t]{4}{*}{ Land cover } & Mean tree canopy coverage ${ }^{a}(1)$ & FM TCC & $\%$ & $\begin{array}{l}\text { Global Forest Change Data- }(30 \mathrm{~m}) \\
\text { (Hansen et al. 2013) }\end{array}$ \\
\hline & Diversity of natural vegetation covers ${ }^{\mathrm{b}}$ (1) & FM DIVVEG & $0-1$ & CORINE Land Cover ${ }^{\mathrm{c}}$ \\
\hline & $\begin{array}{l}\text { Distance to mountain top bare rocks } \\
(>1000 \mathrm{~m} \text { altitude })\end{array}$ & D BROCKS & $\mathrm{m}$ & \\
\hline & $\begin{array}{l}\text { Distance to large rivers } 500 \mathrm{~m} \text { buffer } \\
\quad(\text { Strahler } \mathrm{nr}>2)^{\mathrm{d}}\end{array}$ & D RIVERBND & $\mathrm{m}$ & EU-hydro Danube (EEA) \\
\hline \multirow[t]{4}{*}{ Anthropogenic } & Distance to major roads (E, DN) & D MJROAD & $\mathrm{m}$ & $\begin{array}{l}\text { OpenStreetMap.org available by } \\
\text { MapCruzin.com }\end{array}$ \\
\hline & Barrier effect-2 km band ${ }^{\mathrm{e}}$ & FM BARR EFF & $0-3$ & $\begin{array}{l}\text { EU-hydro Danube (EEA) and } \\
\text { MapCruzin.com }\end{array}$ \\
\hline & Distance to villages & D VILLAGES & $\mathrm{m}$ & CORINE Land Cover \\
\hline & $\begin{array}{l}\text { Distance to large settlements }(>10,000 \\
\text { inhabitants) }\end{array}$ & $\begin{array}{l}\text { D } \\
\text { LGSETTLEM }\end{array}$ & $\mathrm{m}$ & \\
\hline
\end{tabular}

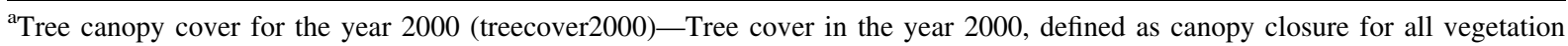
taller than $5 \mathrm{~m}$ in height. Encoded as a percentage per output grid cell, in the range $0-100 \%$

${ }^{\mathrm{b}}$ Index-Mean variety the natural vegetation covers in one cell: mixed forest, deciduous, conifers, shrubs and scattered vegetation and natural grasslands (CLC2018)

${ }^{\mathrm{c}}$ Corine Land Cover 2018 (CLC2018) report about the land use state in 2018, and it is a dataset based on the photo interpretation of satellite images by the national teams of the participating countries. This dataset has a minimum mapping unit (MMU) for status layers of 25 hectares-minimum width of linear elements of $100 \mathrm{~m}$

${ }^{\mathrm{d}}$ Strahler method assigns an order to river streams, this order is a method for identifying and classifying types of streams based on their numbers of tributaries

${ }^{\mathrm{e}}$ Estimated by adding the number of linear barriers, buffered $1 \mathrm{~km}$ : large rivers, railways and the European and National roads with a significant traffic volume (AADT > 3500 cars/day) according to Iuell et al. (2003) classification \& others

estimates (Koen et al. 2014). Much higher current density values are generally obtained in the surroundings of these habitat areas, adding to the difficulty of delineating the areas themselves. To avoid these circumstances and to specifically focus on general connectivity (i.e., regional movement routes), we adopted a 'wall-to-wall' approach based on the technique described in Koen et al. (2014). We used a $50-\mathrm{km}$-wide buffer ( $>20 \%$ of the study area) and placed 60 focal nodes (same source-destination points for male and female models) randomly around the perimeter of the buffered area. The analyses were conducted for the resistance layers derived from the habitat models representing both males and females. The 'pairwise' and 'connections to the eight raster cells neighbours' options were selected within Circuitscape, and the focal node currents were set to zero.

After completion, the buffer area was removed from the resulting cumulative current layers, so the bias around the focal points was eliminated. Finally, we used zonal statistics to analyse the landscape features (elevation, slope, aspect, forest density, proximity to landscape features, number of barriers, and land cover types crossed) coinciding with the highest current densities. Each current map was reclassified into ten categories by natural breaks (the Jenks method) to conduct this analysis, where 1 indicates the most movement-constrained category for bear movement and 10 indicates the most favourable category. This analysis provides information on landscape features and their effect on bear movements to address conservation measures and management actions. Specifically, these categories provide an easily interpretable cartographic product that managers may use as a general zonation, ranked by connectivity provision. 
Quantifying the similarities among sex-specific models

To complement and support the obtained results, we assessed the model's spatial discrepancies using Cohen's kappa statistic coefficient $(\kappa)$ and the Phi coefficient $(\Phi)$ as quantitative metrics to test the differences mentioned above between males and females brown bear movement patterns in our models. In particular, the Phi coefficient estimates an association rate between binary variables (Everitt 2006; Frey 2018; Kalgotra et al. 2020), whereas the kappa statistic allows measuring the agreement degree while considering multiple variables (McHugh 2012; Verma et al. 2020). The habitat, resistance and cumulative current density models were classified into (i) 2 categories (binary maps based on bear presence probability thresholds) and (ii) 10 categories divided by natural breaks thresholds (Jenks method) (Polfus et al. 2014; Peters et al. 2015). Then, 10,000 random points were generated, considering the same number of points distributed within each category, and the female and male models were intersected. Finally, to estimate the selected metrics, we computed the confusion matrix and created randomly sampled points for the postclassification accuracy assessment using segmentation and classification tools in ArcGIS.

\section{Identifying priority areas for connectivity}

As a further step in this study, we designed a new operational method to identify priority areas regarding connectivity across the main pathways obtained from Circuitscape. Specifically, the following approach consists of a classification of the high cumulative current flows of female and male bears according to their conservation concern. First, we applied the "Focal Statistics-Mean" tool in ArcGIS v.10.6, using moving windows of $0.5 \mathrm{~km}$ and $2-\mathrm{km}$ radius (2- and 8-cell-wide radii), to create two different raster maps based on the female and male bears' cumulative current densities. Then, we used the Raster Calculator function in ArcGIS to obtain two maps by subtracting (a) the focal means within a 2-cell radius from the Circuitscape cumulative current values and (b) the focal means estimated within an 8-cell radius from the focal means within a 2-cell radius.

For further analysis, we only considered the resulting areas with the highest current flow values obtained from each Circuitscape model (5-10 classes obtained previously by the Jenks method), and the main pathways expected to be used when moving across the study region by females and males. Cells with high positive values in both subtractions depicted higher probabilities of moving through adjacent cells than through others located farther away. Hence, these cells are expected to funnel bear movements through smaller areas and, therefore, were defined as priority areas for connectivity. In summary, cells were considered priority areas if they met the following criteria simultaneously: (i) within an area that matches the cumulative current value greater than the 90th percentile (Circuitscape outputs); (ii) with a cumulative current value ( $>90$ th percentile) greater than the focal mean within a 2-cell radius; (iii) the focal means within a 2-cell radius were greater than the focal means within an 8-cell radius.

This method allowed us to explore the aptitude offered by the land next to the predicted main pathways. Specifically, it allowed the identification of high-quality areas for connectivity constrained by remaining high resistances in the surroundings that could limit the flow of individuals across the landscape (Mateo-Sánchez et al. 2014; Ghoddousi et al. 2020; Jalkanen et al. 2020). Once we defined the highpriority areas across the main pathways for both female and male bears, we combined them in a unique spatial map to identify the priority zones to preserve species connectivity. Moreover, we elaborated a management configuration framework to encourage evidence-based conservation.

\section{Results}

Brown bear sex-specific habitat models and covariate contributions

All the models showed common patterns and several discrepancies between male and female bears environmental preferences. Overall, the distance to bare rock areas on hilly sites and the proximity to large settlements explained $85 \%$ of the re-evaluated model predictions, followed by the tree canopy coverage, slope and distance to large rivers. On the other hand, the lowest contribution rates were assigned to the barrier effect estimation considering rivers, major roads and railways and the vegetation diversity index 
Table 2 Mean relative contribution over replicate runs (\%) of the eight most influential covariates considered in the definite models

\begin{tabular}{llll}
\hline Variable category & Environmental covariates description (scale in km) & Female & Male \\
\hline Topography & Mean slope (1) & 2.5 & 2.9 \\
Land cover & Mean tree canopy coverage (1) & 5.5 & 2.6 \\
& Distance to top hill bare rock surface $(>1000 \mathrm{~m})$ & 60.6 & 83.1 \\
& Distance to large rivers, buffered 500 m (Strahler number $>2)$ & 1.7 & 2.7 \\
Anthropogenic & Distance to major roads (E, DN) & 2.4 & 1.5 \\
& Barrier effect band of 2 km & 0.3 & 2.1 \\
& Distance to villages & 0.5 & 2.2 \\
& Distance to large settlements (> 10,000 inhabitants) & 26.5 & 3.1 \\
& & 100 & 100 \\
\hline
\end{tabular}

(Table 2). However, forest cover made meagre contributions to the prediction models when considered with all the environmental features. Regarding the accuracy of the models, all the species distribution models had good predictive performances, inferred by small variabilities among replicate models and good discrimination abilities (AUC > 0.9) (Swets 1988).

\section{Resistance surfaces}

Notable differences were identified between the female and male resistance surfaces. Regarding the estimated resistance graphic depictions, the female bear models show large and isolated areas with lower resistance values, while the male models depicted less fragmented and irregular low-resistance areas. However, both maps depicted high-resistance areas cutting across the mountain range (see Supplementary Material, Fig. S1). Furthermore, similarities were found between the cumulative resistance values and frequencies matching the female and male bear locations. Male bears, overall, moved through higher-resistance areas than females (Supplementary Material, Fig. S2).

\section{Connectivity and model similarities}

The final cumulative current flow maps, obtained by employing the Circuitscape outputs, also showed significant disagreements between the spatial patterns of female and male brown bear movements (Fig. 3). Clearer and more continuous corridor areas were found in the male bears' connectivity model (Fig. 3a). On the other hand, we noticed potential alternate paths in the female bear model (Fig. 3b), shaping different branching lines from south to north around the mountain-top areas. It is worth noting that the predicted movement routes mainly avoid the large urban areas depicted in Fig. 3. However, both maps show higher current density areas in the vicinity of the Predeal urban area, especially the females' map.

The zonal analysis of landscape features and deciles' classified current density models inferred distinct and common bear movement behaviour patterns. Specifically, we examined landscape feature values coinciding with the highest current flow density classes (5-10) (Supplementary Material, Table S6 and Fig. S3).

For both sexes, the high-current-density areas coincided with mid-elevation areas and low-grade landscapes $(<30 \%)$ covered by forests, with no linear barriers. Nevertheless, according to the intersected ranges, female bears tended to move through higher elevations close to bare rock areas and across steeper lands than males. Moreover, the analysis indicated that males preferred to move through denser vegetation covers than females and areas near large rivers. In addition, regarding aspect, the results reflect that bears like to move across areas facing the northwest. The highest current flow values matched north-eastern facing slopes most often for males and western exposures for females. On the other hand, anthropic factors (densely populated urban areas and linear infrastructures) were generally avoided by bears when moving across the landscape. In contrast, the bear's minimum distances to these intervening areas indicated that anthropic pressures have a lesser effect on female movements than males. 


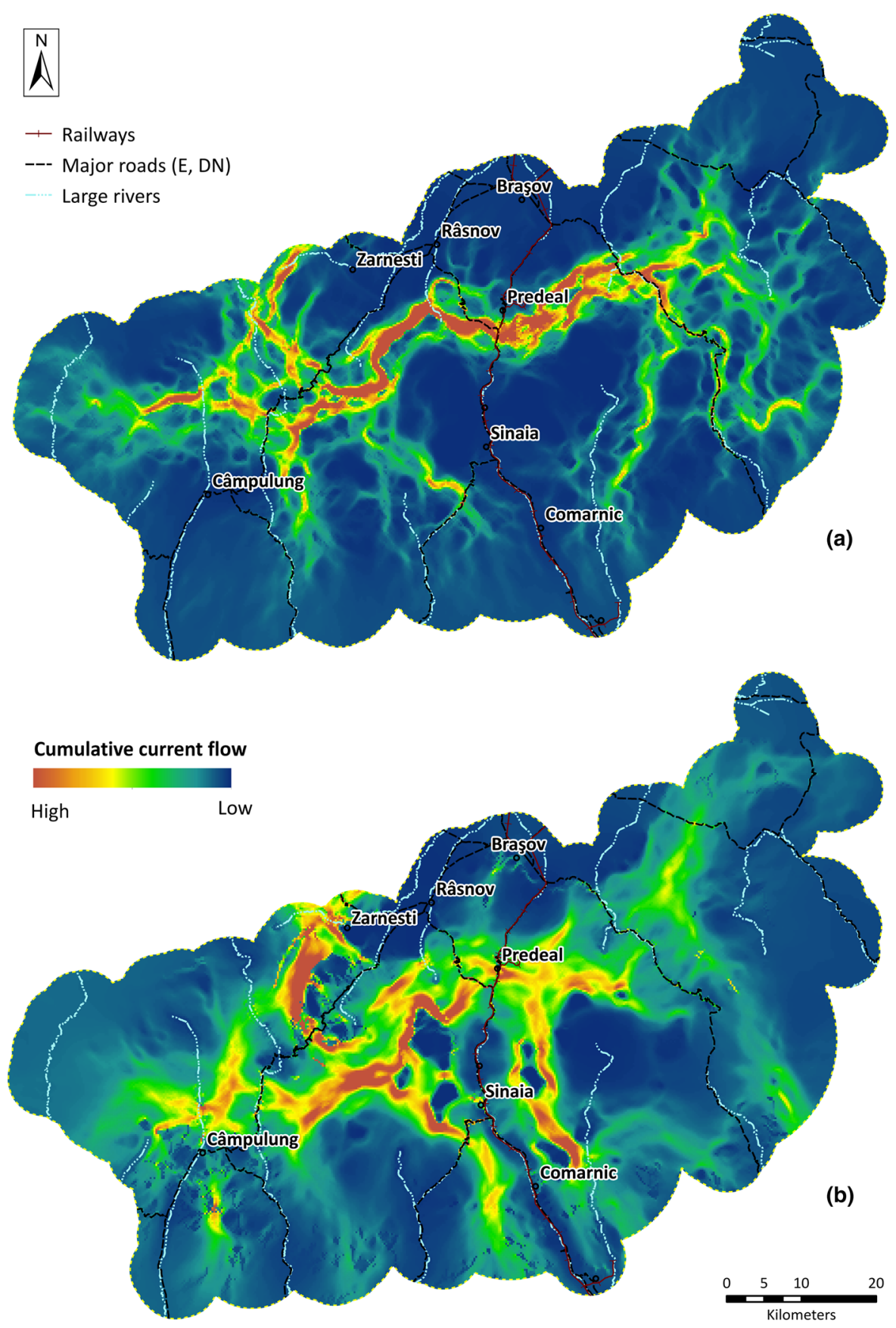

Fig. 3 Cumulative current density maps from Circuitscape for male (a) and female (b) brown bears. Red directional bands depict the most likely areas to be used by the species to move through the study landscape, and blue areas are related to low passage probabilities

The metrics used to quantify similarities between the resulting connectivity models reflect remarkable disagreements that exist between the female and male maps (with kappa and phi coefficient values close to 0 ). When reclassified into ten classes, the estimated model coefficients showed lower metrics than those obtained from the binary maps. Moreover, according to the estimated metrics, the connectivity models showed higher disagreement between females and males than the other models of our study (i.e. habitat 
and resistance) (Supplementary Material, Table S7), and the habitat models obtained the highest agreement values.

High-quality areas for bear connectivity conservation-a new operational method

Our new method allowed us to delimit the main pathways taken by female and male bears, to obtain the cells related to their highest movement probabilities, and to identify the areas across these movement routes that should be prioritised for conservation planning (Fig. 4a, b). The overlapping priority areas between female and male bears are depicted in Fig. 4c. The main pathway cells that were not categorized as priority areas were considered zones of least concern and mainly were located in the main pathway borders in the maps shown in panels (a) and (b) of Fig. 4.

\section{Discussion}

Our connectivity models indicated deviations between female and male bear behaviours and confirmed our methodological framework as an essential tool for designing distinct and more specific management actions. The statistical metrics reflected increased disparities between the female and male bear models when transferring the MaxEnt models to Circuitscape connectivity models. The high bear population densities can explain spatial disagreements observed in these connectivity models, different behaviour and landscape preferences for females and males-e.g. females avoidance of males dispersal paths to protect their cubs (Mertzanis et al. 2005; Rode et al. 2006; Pop et al. 2012). Moreover, the current rates and continuous spatial patterns observed in our current density maps imply that males are more related to the species dispersal events than female brown bears. In contrast, females' current flows patterns could be linked to their shorter movements within and among habitat areas and bear feeding behaviours, which are mostly related
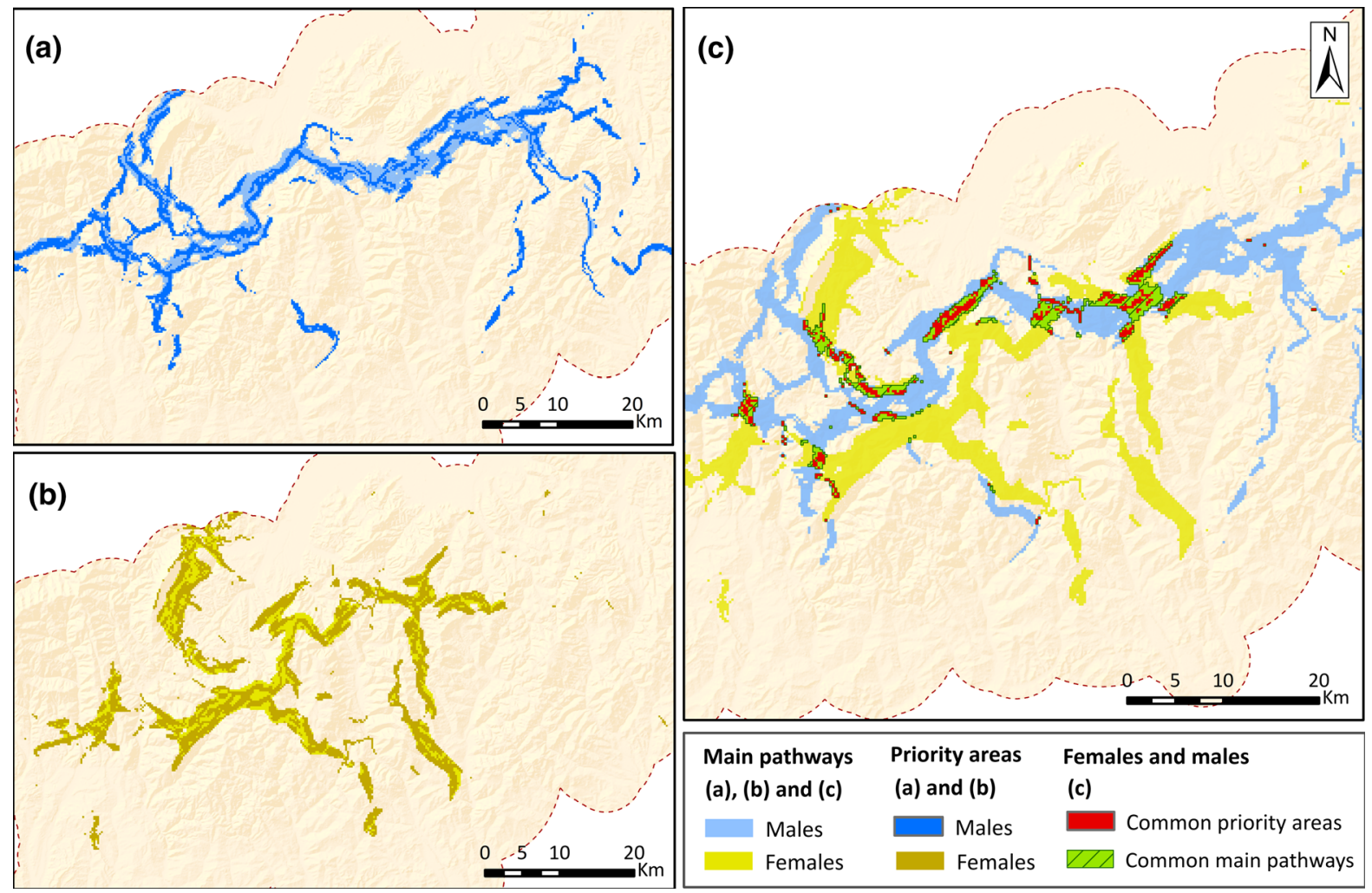

Fig. 4 Main pathways and high-priority areas for male (a), female (b) and both (c) 
to individuals keeping cubs (Støen 2006; Ziółkowska et al. 2016; Maiorano et al. 2017; Bartoń et al. 2019; Fedorca et al. 2019). We highlight the specific discrepancies of bears regarding population dispersal according to their sexes: female bear expansion is vital to support stable and robust populations, while male dispersals are linked to the pursuit of new habitats contributing to preserving genetic connectivity (Wiegand et al. 2004).

The exploratory analysis of the habitat models provided a better understanding of female and male bear perceptions in terms of resistance to movement determined across landscapes. Moreover, similar studies have shown that predictions were primarily influenced by the elevation factors inferred from the models' most powerful variables and confirmed by bears behaviour (Apps et al. 2004; Pop et al. 2012). Low contributions obtained for forest covers could be determined by the high forest continuity on the studied landscape, as was also inferred by Fedorca et al. 2019. Northwest facing aspects coincides with bear movement routes and is related to forest types that provide seasonal foraging and relief needs of bears (Chmura 2008; Ciucci et al. 2014; Fedorca et al. 2019), with no real preference for forest composition (Maanen et al. 2006). Moreover, areas near the large rivers are the most productive areas for bear food, and our models predicted that these areas are suitable for males and avoided by females with cubs. Previous research studies have stated that bears choose to move through gently sloping areas due to energetic constraints (Fedorca et al. 2019). Nevertheless, although both sexes selected low to moderate slopes to move through, we inferred that the female tolerance for steep slopes is slightly increased compared to that of males.

Additionally, we deduced females' and males' tolerances to the anthropic factors considered in our models. We noticed a higher tolerance of female bears than male bears to major roads on the cumulative current maps. These outcomes could be influenced by the aforementioned high degree of naturalness and continuity of forest cover across a large part of the studied region within the Romanian Carpathian range. On the other hand, the high movement rates of females close to large settlements could be due to the large number of male bears in the territory pushing females towards anthropic areas. Furthermore, while males prefer to stay in farther areas, females with yearling cubs frequent areas near villages, which are influenced by livestock grazing from May to September, in addition to dogs and shepherding activities (Rigg and Adamec 2007; Rastrelli et al. 2015). Additionally, the occurrence rates output by the male prediction models seemed to correlate with the river courses near infrastructures traversing the bottoms of valleys (Fedorca et al. 2019). The discussed inferences from each sex are helpful to address management actions for maintaining or improving landscape permeability to the brown bear movement (Ghoddousi et al. 2020) and preventing human-bear conflicts or other unfortunate incidents such as wildlife-vehicle collisions.

Furthermore, according to the high-quality connectivity areas, we located three priority areas of high conservation importance in the study area for both female and male bears (Fig. 5). These areas are mainly affected by two current and emerging linked factors: urban sprawl and tourism impacts (Fig. 5b) and hightraffic roads (Fig. 5a, c). The priority area delineated in Fig. 5c was also remarked on in previous studies by Fedorca et al. $(2019,2020)$ due to its high conservation value. The loss of these identified high-quality areas for connectivity could compromise the functionality of the whole corridor (Dondina et al. 2020). Therefore, the noted key areas should be acknowledged as potential connectivity bridges linking sites of high conservation value, especially in sections where the main pathway progressively narrows (Romportl et al. 2013). Moreover, the continuity and high quality of the remaining areas from broader pathways could significantly uphold the species connectivity against landscape degradation.

Combining the final results obtained for females and males provided new knowledge on which areas bears use for all dispersal, feeding and reproduction activities (see Fig. 6). Moreover, as a well-known approach to infer dispersal behaviours, our results are in accordance with landscape genetics results (Fedorca et al. 2019, 2020). Thus, the high-quality connectivity conservation areas obtained herein are considered solid, science-based evidence and are more than approximate hints to go on regarding the prioritisation of mitigation locations.

Spatially optimized management strategies based on the specific patterns found among models should address female and male requirements, such as promoting dispersal movements through male-specific main pathways to ensure gene flow among populations 


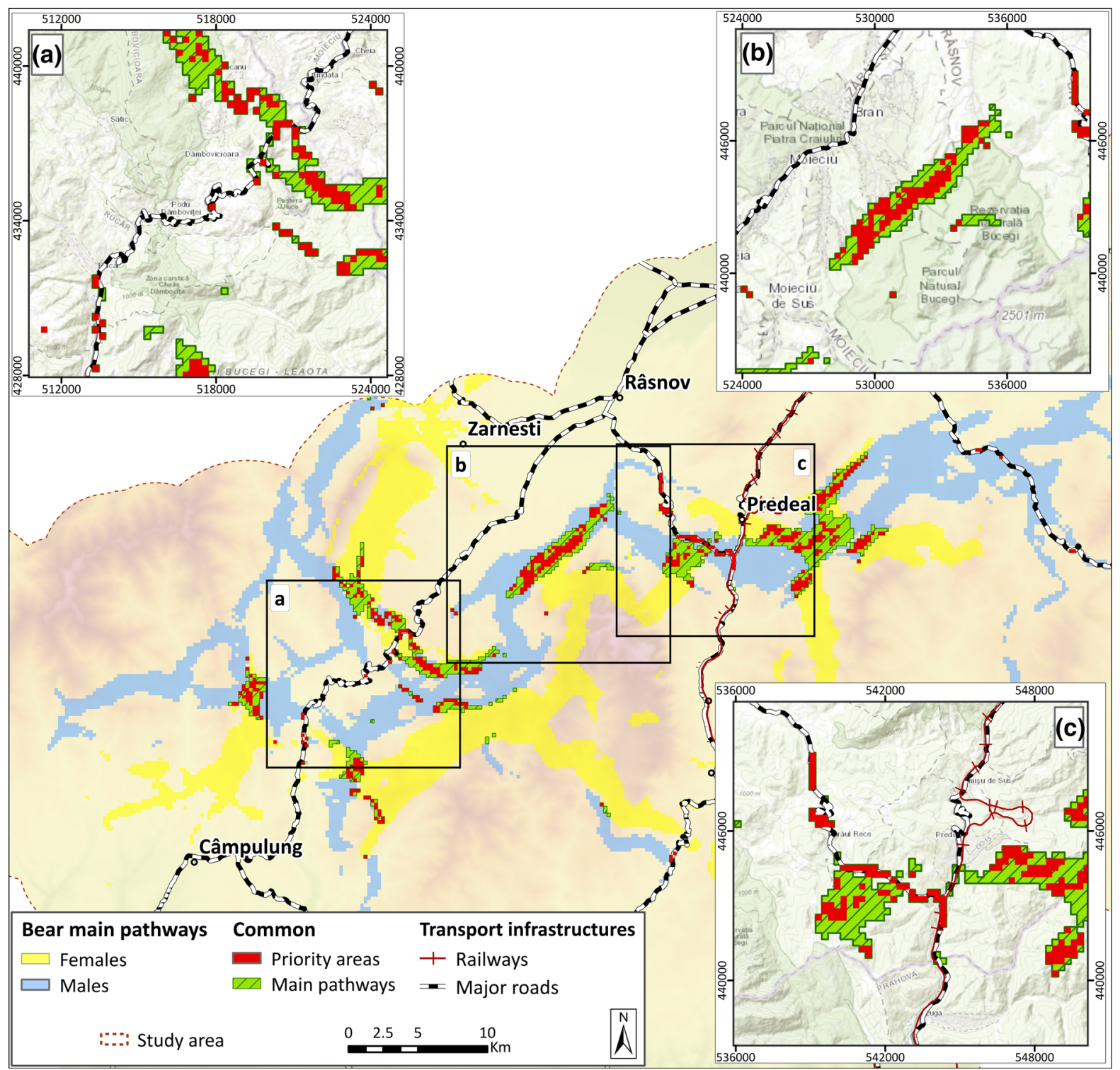

Fig. 5 Common high-priority areas for conservation of bear connectivity across the main pathways for female and male bears. Zoom to main pathways' locations constrained by major roads and urban areas

and integrating mitigation and cost-effective measures in future linear infrastructure constructions (Huck et al. 2010; Daranova et al. 2012). European and national laws and regulations provide legal bases for protecting large carnivore populations and their ecological corridors. Although the execution of the current legislation is weak and cooperation in sectorial policymaking is lacking, the maintenance of existing forests, wildlife management and land use preservation, accompanied by the issuance of conservation easements, could provide protection. The results obtained herein may reinforce the demand to fulfil protection law provisions by integrating ecological corridors, as defined by Hilty et al. (2020). Ultimately, the transferability of the obtained outputs to managers and stakeholders is essential to implement integrated practical conservation solutions and drive 'smart' development in rising regions such as the Carpathians.

Therefore, we opt for well-known connectivity approaches based on the latest research and 


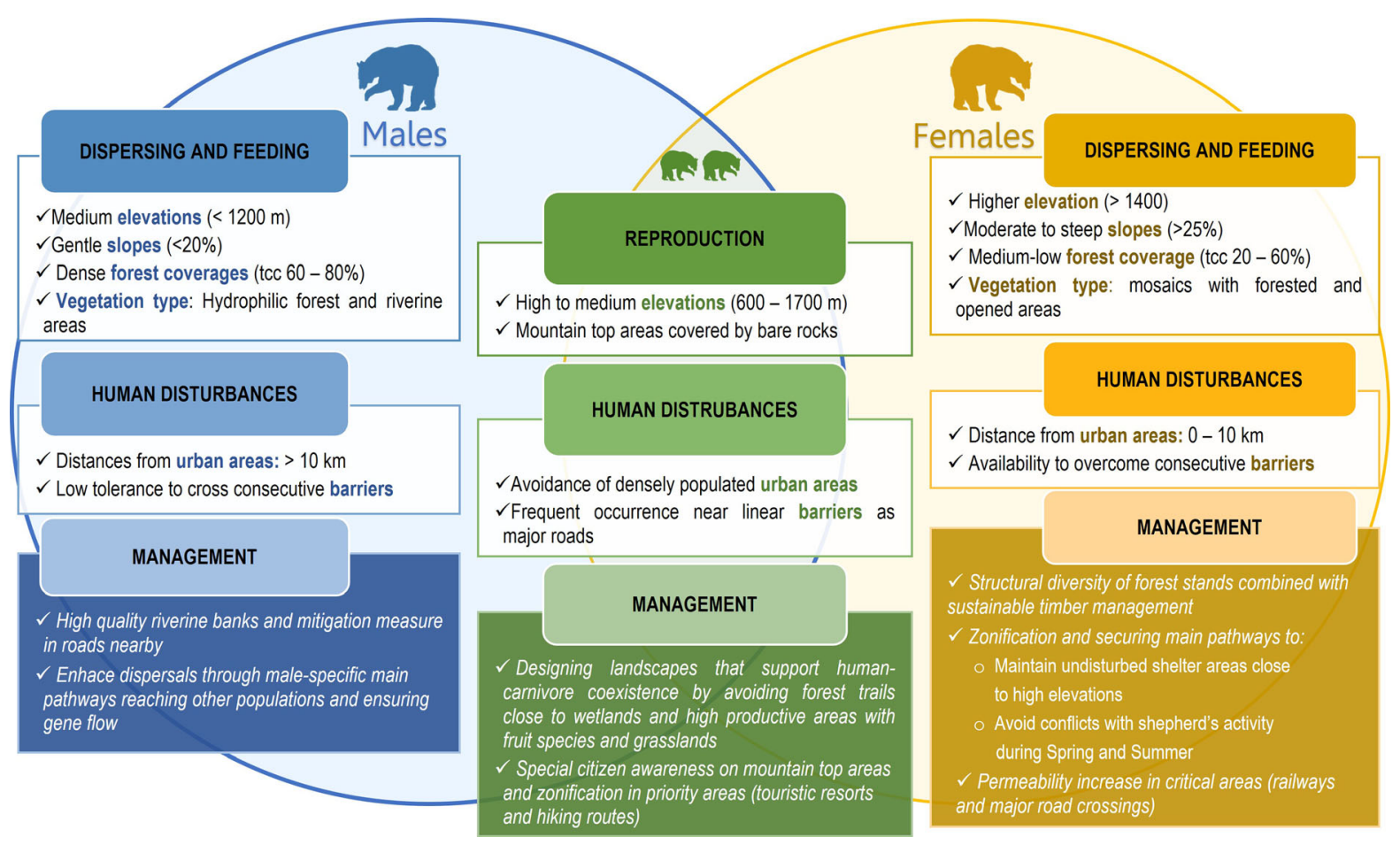

Fig. 6 Management scheme based on sex-specific and common bear movement patterns for securing connectivity

international experience adapted and expanded to our specific focal species needs; and enhanced with particular innovations as those integrated into our modelling approach. The most remarkable features we incorporated into previous approaches consisted of feeding the MaxEnt modelling only with presences linked to movements, zoning the whole study area regarding females and males connectivity, and designing a simple pattern recognition procedure to identify priority areas from Circuitscape results. We strongly believe there is an interesting research line in this regard, as managers ask for more objective and reproducible results than just the visual interpretation of the current density map. In order to improve this approach, sex-specific connectivity models could be implemented by other methods, including alternative descriptive models and seasonality analyses, to expand the analyses (Epps et al. 2007; Güthlin et al. 2011; van de Kerk et al. 2015; Keeley et al. 2017; Fedorca et al. 2019; Zeller et al. 2019). Moreover, we encourage the connectivity research community to explore pattern recognition algorithms applied to Circuitscape outputs, for example, the Morphological Spatial Pattern Analysis (MSPA) (Soille and Vogt 2009) implemented in the GuidosToolbox software
(Vogt and Riitters 2017), but also others coming from biometrics or other fields.

\section{Conclusions}

Sex-biased behavioural and ecological characteristics have important implications for brown bear connectivity conservation. Therefore, it is essential to integrate these features in connectivity assessments. This study identified specific habitat selection patterns of female and male brown bears, transferred them to connectivity models, and mapped potential mitigation corridors by combining different modelling, statistical and spatial analysis approaches. The high degrees of discrepancy obtained among female and male models demonstrated the importance of using sex-specific models for males and females to study brown bear movement patterns. Moreover, the interdisciplinary methodological framework applied herein was considered suitable for defining bears' potential movement paths across the study area since we contrasted our results with those of previous studies and found plentiful concurrences. 
Our results allow conservation planners and managers to set conservation goals and foster wellinformed decisions for practical problems based on both sexes' movement assessments and habitat needs, with a high potential to cover many other species' needs under the brown bear umbrella effect. Moreover, these results support landscape planners in opting for mitigation solutions and ensuring connectivity through ecological networks and corridors, especially those focused on securing the continuity and high quality of the priority areas identified across the main pathways. We advocate for establishing an ecological network, based on interdisciplinary approaches results as ours, in conjunction with local communities, supporting traditional forest practices, wildlife management, and land use preservation and promoting smart and sustainable development. Additionally, we raise new research directions on further landscape connectivity assessments to implement complementary conservation measures, such as human-wildlife conflict mitigations.

To conclude, the results of this study are intended to support previous research work to provide suitable solutions to practical problems by contributing to the decision-making processes. We suggest including connectivity targets within environmental and impact assessments, urgently adopting conservation easements, and creating synergies between researchers, local communities, conservation managers, planners, and decision-makers to ensure a coherent ecological network for brown bears and many other species in the Carpathian region.

Acknowledgements $\mathrm{We}$ are thankful to the entire team Cinegetica from INCDS Marin Dracea (National Institute for Research and Development in Forestry Marin Dracea), who contributed to gathering the analysed dataset.

Author contributions All authors contributed to the study conception and design. Material preparation MPG-S and AF, data collection and analysis were performed by RJ, MPG-S, SGÁ, JS-G, MP, MF, GI, OI and AF. The first draft of the manuscript was written by MPG-S and AF and all authors commented on previous versions of the manuscript. MPG-S and AF contributed equally. All authors read and approved the final manuscript.

Funding Partial financial support was received from the National Institute for Research and Development in Forestry Marin Dracea from the projects Life for Bear (LIFE 13NAT/ RO/001154, LIFE17NAT/IT/464 SAFE-CROSSING, BEAR around Brasov, Nucleu Programme from ANCSI-
PN19070601, BearConnect funded under BiodivERsA3-2015147-BearConnect (96/2016) and was supported by MONTESSchool of Forest Engineering and Natural Environment. Universidad Politécnica de Madrid (UPM).

Data availability All relevant data are within the paper (Please, see tables and figures).

Code availability Will be made available online on a repository database.

\section{Declarations}

Conflict of interest The authors have declared that no competing interests exist. All views and opinions expressed here remain the author's sole responsibility and do not necessarily represent those of the INCDS Marin Dracea.

Ethical approval Yes.

Informed consent Yes.

Open Access This article is licensed under a Creative Commons Attribution 4.0 International License, which permits use, sharing, adaptation, distribution and reproduction in any medium or format, as long as you give appropriate credit to the original author(s) and the source, provide a link to the Creative Commons licence, and indicate if changes were made. The images or other third party material in this article are included in the article's Creative Commons licence, unless indicated otherwise in a credit line to the material. If material is not included in the article's Creative Commons licence and your intended use is not permitted by statutory regulation or exceeds the permitted use, you will need to obtain permission directly from the copyright holder. To view a copy of this licence, visit http://creativecommons.org/licenses/by/4.0/.

\section{References}

Apps CD, McLellan BN, Woods JG, Proctor MF (2004) Estimating grizzly bear distribution and abundance relative to habitat and human influence. $J$ Wildl Manag 68(1):138-152. https://doi.org/10.2193/0022-541x

Ashrafzadeh MR, Khosravi R, Adibi MA, Taktehrani A, Wan HY, Cushman SA (2020) A multi-scale, multi-species approach for assessing effectiveness of habitat and connectivity conservation for endangered felids. Biol Conserv 245:108523

Bartoń KA, Zwijacz-Kozica T, Zięba F, Sergiel A, Selva N (2019) Bears without borders: long-distance movement in human-dominated landscapes. Glob Ecol Conserv 17:1-8

Beier P, Majka DR, Spencer WD (2008) Forks in the road: choices in procedures for designing wildland linkages. Conserv Biol 22(4):836-851

Cazacu C, Adamescu MC, Ionescu O, Ionescu G, Coţovelea A, Jurj R, Popa M, Cazacu R (2014) Mapping trends of large and medium size carnivores of conservation interest in 
Romania. Ann For Res 57(1):97-107. https://doi.org/10. 15287/afr.2014.170

Chapron G, Kaczensky P, Linnell JDC, Von Arx M, Huber D, Andrén H, López-Bao JV, Adamec M, Álvares F, Anders O, Balečiauskas L, Balys V, Bedõ P, Bego F, Blanco JC, Breitenmoser U, Brøseth H, Bufka L, Bunikyte R, Boitani L (2014) Recovery of large carnivores in Europe's modern human-dominated landscapes. Science 346(6216):1517-1519

Chmura D (2008) The slope aspect affects the heterogeneity and growth of ground flora vegetation in deciduous temperate forest. Pol J Ecol 56:463-470

Ciucci P, Tosoni E, Domenico GDI, Quattrociocchi F, Boitani $\mathrm{L}$, (2014) Seasonal and annual variation in the food habits of Apennine brown bears, Seasonal and annual variation in the food habits of Apennine brown bears, central Italy. J Mammal 95:572-586

Cristescu B, Domokos C, Teichman KJ, Nielsen SE (2019) Large carnivore habitat suitability modelling for Romania and associated predictions for protected areas. PeerJ 7:e6549

Cushman SA, Lewis JS (2010) Movement behavior explains genetic differentiation in American black bears. Landsc Ecol 25(10):1613-1625

Dahle B, Swenson JE (2003) Home ranges in adult Scandinavian brown bears (Ursus arctos): effect of mass, sex, reproductive category, population density and habitat type. J Zool 260(4):329-335

Dai Y, Hacker CE, Zhang Y, Li W, Zhang Y, Liu H, Zhang J, Ji Y, Xue Y, Li D (2019) Identifying climate refugia and its potential impact on Tibetan brown bear (Ursus arctos pruinosus) in Sanjiangyuan National Park, China. Ecol Evol 9(23):13278-13293

Daranova A, Griniece E, Michal M, Reid A (2012) Connecting smart and sustainable. Growth through smart specialisation. A practical guide for ERDF managing authorities. European Union. https://doi.org/10.2776/70221

D'Elia J, Brandt J, Burnett LJ, Haig SM, Hollenbeck J, Kirkland S, Marcot BG, Punzalan A, West CJ, Williams-Claussen T, Wolstenholme R, Young R (2019) Applying circuit theory and landscape linkage maps to reintroduction planning for California Condors. PLoS ONE 14(12):1-22

Diniz MF, Cushman SA, Machado RB, De Marco JP (2020) Landscape connectivity modeling from the perspective of animal dispersal. Landsc Ecol 35(1):41-58

Dondina O, Orioli V, Torretta E, Merli F, Bani L, Meriggi A (2020) Combining ensemble models and connectivity analyses to predict wolf expected dispersal routes through a lowland corridor. PLoS ONE 15(2):1-16

Dormann CF, McPherson JM, Araújo MB, Bivand R, Bolliger J, Carl G, Davies R, Hirzel A, Jetz W, Daniel Kissling W, Kühn I, Ohlemüller R, Peres-Neto P, Reineking B, Schröder B, Schurr F, Wilson R (2007) Methods to account for spatial autocorrelation in the analysis of species distributional data: a review. Ecography 30(5):609-628

Dudík M, Phillips SJ, Schapire RE (2007) Maximum entropy density estimation with generalized regularization and an application to species distribution modeling. J Mach Learn Res 8(44):1217-1260. https://doi.org/10.5555/1314498. 1314540
Duflot R, Avon C, Roche P, Bergès L (2018) Combining habitat suitability models and spatial graphs for more effective landscape conservation planning: an applied methodological framework and a species case study. J Nat Conserv 46:38-47

Elith J, Graham C, Anderson R, Dudík M, Ferrier S, Guisan A, Hijmans R, Huettmann F, Leathwick J, Lehmann A, Li J, Lohmann L, Loiselle B, Manion G, Moritz C, Nakamura M, Nakazawa Y, McC M, Overton J, Townsend Peterson A, Zimmermann N (2006) Novel methods improve prediction of species' distributions from occurrence data. Ecography 29(2):129-151

Elith J, Phillips SJ, Hastie T, Dudík M, Chee YE, Yates CJ (2011) A statistical explanation of MaxEnt for ecologists. Divers Distrib 17(1):43-57

Epps CW, Wehausen JD, Bleich VC, Torres SG, Brashares JS (2007) Optimizing dispersal and corridor models using landscape genetics. J Appl Ecol 44(4):714-724. https://doi. org/10.1111/j.1365-2664.2007.01325.x

Everitt BS (2006) The Cambridge dictionary of statistics, 3rd edn. Cambridge University Press, New York

Falcucci A, Maiorano L, Ciucci P, Garton EO, Boitani L (2009) Land-cover change and the future of the Apennine Brown bear: a perspective from the past. J Mammal 89:1502-1511

Fedorca A, Russo IRM, Ionescu O, Ionescu G, Popa M, Fedorca M, Curtu AL, Sofletea N, Tabor GM, Bruford MW (2019) Inferring fine-scale spatial structure of the brown bear (Ursus arctos) population in the Carpathians prior to infrastructure development. Sci Rep 9(1):1-12

Fedorca A, Popa M, Jurj R, Ionescu G, Ionescu O, Fedorca M (2020) Assessing the regional landscape connectivity for multispecies to coordinate on-the-ground needs for mitigating linear infrastructure impact in Brasov-Prahova region. J Nat Conserv 58:125903

Fernández N, Selva N, Yuste C, Okarma H, Jakubiec Z (2012) Brown bears at the edge: modeling habitat constrains at the periphery of the Carpathian population. Biol Conserv 153:134-142

Fourcade Y, Engler JO, Rödder D, Secondi J (2014) Mapping species distributions with MAXENT using a geographically biased sample of presence data: a performance assessment of methods for correcting sampling bias. PLoS ONE 9(5):1-12

Frey B (2018) The SAGE encyclopedia of educational research, measurement, and evaluation, vol 1-4. SAGE Publications Inc, Thousand Oaks

Gantchoff M, Conlee L, Belant J (2019) Conservation implications of sex-specific landscape suitability for a large generalist carnivore. Divers Distrib 25(9):1488-1496. https://doi.org/10.1111/ddi.12954

García P, Lastra J, Marquínez J, Nores C (2007) Detailed model of shelter areas for the Cantabrian brown bear. Eco Inform 2:297-307

Ghoddousi A, Bleyhl B, Sichau C, Ashayeri D, Moghadas P, Sepahvand P, Kh Hamidi A, Soofi M, Kuemmerle T (2020) Mapping connectivity and conflict risk to identify safe corridors for the Persian leopard. Landsc Ecol 35(8):1809-1825

Glover-Kapfer P (2018) A training manual for habitat suitability and connectivity modeling. PhD Thesis, WWF, Bhutan https://doi.org/10.13140/RG.2.2.34804.86409 
Güthlin D, Knauer F, Kneib T, Küchenhoff H, Kaczensky P, Rauer G, Jonozovič M, Mustoni A, Jerina K (2011) Estimating habitat suitability and potential population size for brown bears in the Eastern Alps. Biol Conserv 144(5):1733-1741. https://doi.org/10.1016/j.biocon.2011. 03.010

Hermes C, Keller K, Nicholas RE, Segelbacher G, Martin Schaefer H (2018) Projected impacts of climate change on habitat availability for an endangered parakeet. PLoS ONE 13(1):1-17

Hilty J, Worboys G, Keeley A, Woodley S, Lausche B, Locke H, Carr M, Pulsford I, Pittock J, White W, Theobald D, Levine J, Reuling M, Watson J, Ament R, Tabor G (2020) Guidance for conserving connectivity through ecological networks and corridors. IUCN 30:140

Huck M, Jedrzejewski W, Borowik T, Miłosz-Cielma M, Schmidt K, Jedrzejewska B, Nowak S, Mysłajek RW (2010) Habitat suitability, corridors and dispersal barriers for large carnivores in Poland. Acta Theriol 55(2):177-192

Iuell B, Bekker HGJ, Cuperus R, Dufek J, Fry G, Hicks C, Hlavác V, Keller V, Rosell C, Sangwine T, Tørsløv N, Wandall BM (2003) Wildlife and traffic: a European handbook for identifying conflicts and designing solutions. COST 341 "Habitat Fragmentation Due to Transportation Infrastructure." KNNV Publishers, Netherlands

Jalkanen J, Toivonen T, Moilanen A (2020) Identification of ecological networks for land-use planning with spatial conservation prioritization. Landsc Ecol 35(2):353-371

Jerina K, Jonozovič M, Krofel M, Skrbinšek T (2013) Range and local population densities of brown bear Ursus arctos in Slovenia. Eur J Wildl Res 59(4):459-467. https://doi.org/ 10.1007/s10344-013-0690-2

Kabir M, Hameed S, Ali H, Bosso L, Din JU, Bischof R, Redpath S, Nawaz MA (2017) Habitat suitability and movement corridors of grey wolf (Canis lupus) in Northern Pakistan. PLoS ONE 12(11):1-17

Kalgotra P, Sharda R, Luse A (2020) Which similarity measure to use in network analysis: impact of sample size on phi correlation coefficient and Ochiai index. Int J Inf Manag 55:102229

Karelus DL, McCown JW, Scheick BK, Van De Kerk M, Bolker BM, Oli MK (2017) Effects of environmental factors and landscape features on movement patterns of Florida black bears. J Mammal 98(5):1463-1478

Keeley ATH, Beier P, Keeley BW, Fagan ME (2017) Habitat suitability is a poor proxy for landscape connectivity during dispersal and mating movements. Landsc Urban Plan 161:90-102

Koen EL, Bowman J, Sadowski C, Walpole AA (2014) Landscape connectivity for wildlife: development and validation of multispecies linkage maps. Methods Ecol Evol 5(7):626-633

Kramer-Schadt S, Niedballa J, Pilgrim J D, Schröder B, Lindenborn J, Reinfelder V, Stillfried M, Heckmann I, Scharf AK, Augeri DM, Cheyne SM., Hearn AJ, Ross J, Macdonald DW, Mathai J, Eaton J, Marshall AJ, Semiadi G, Rustam R, Wilting A (2013) The importance of correcting for sampling bias in MaxEnt species distribution models. Divers Distrib 19(11):1366-1379. https://doi.org/10.1111/ ddi.12096
Lewis JS, Rachlow JL (2011) Activity patterns of black bears in relation to sex, season, and daily movement rates. West $\mathrm{N}$ Am Nat 71(3):388-395

Liu C, Berry PM, Dawson TP, Pearson RG (2005) Selecting thresholds of occurrence in the prediction of species distributions. Ecography 28(3):385-393

Liu C, Newell G, White M, Bennett AF (2018) Identifying wildlife corridors for the restoration of regional habitat connectivity: a multispecies approach and comparison of resistance surfaces. PLoS ONE 13(11):1-14

Maanen E van, Predoiu G, Klaver R, Soulé M, Popa M, Ionescu O, Jurj R, Altenburg W (2006) Safeguarding the Romanian Carpathian ecological network. A vision for large carnivores and biodiversity in Eastern Europe. A\&W ecological consultants, Veenwouden, The Netherlands. Icas Wildlife Unit, Braşov, Romania

Maiorano L, Boitani L, Chiaverini L, Ciucci P (2017) Uncertainties in the identification of potential dispersal corridors: the importance of behaviour, sex, and algorithm. Basic Appl Ecol 21:66-75

Manel S, Williams CH, Ormerod SJ (2001) Evaluating presence-absence models in ecology: the need to account for prevalence. J Appl Ecol 38:921-931

Mateo-Sánchez MC, Cushman SA, Saura S (2014) Connecting endangered brown bear subpopulations in the Cantabrian Range (north-western Spain). Anim Conserv 17(5):430-440

Mateo Sánchez MC, Cushman SA, Saura S (2014) Scale dependence in habitat selection: the case of the endangered brown bear (Ursus arctos) in the Cantabrian Range (NW Spain). Int J Geogr Inf Sci 28(8):1531-1546

Mateo-Sánchez MC, Balkenhol N, Cushman S, Pérez T, Domínguez A, Saura S (2015a) Estimating effective landscape distances and movement corridors: comparison of habitat and genetic data. Ecosphere 6(4):59

Mateo-Sánchez MC, Balkenhol N, Cushman S, Pérez T, Domínguez A, Saura S (2015b) A comparative framework to infer landscape effects on population genetic structure: are habitat suitability models effective in explaining gene flow? Landsc Ecol 30(8):1405-1420

McHugh ML (2012) Lessons in biostatistics interrater reliability: the kappa statistic. Biochemica Medica 22(3):276-282

McRae B, Dickson BG, Keitt TH, Shah VB (2008) Using circuit theory to model connectivity in ecology, evolution, and conservation. Ecology 89(10):2712-2724

McRae B, Shah VB, Edelman A (2016) Circuitscape: modeling landscape connectivity to promote conservation and human health. Fort Collins, The Nature Conservancy. https://doi.org/10.13140/RG.2.1.4265.1126

Merow C, Smith MJ, Silander JA (2013) A practical guide to MaxEnt for modeling species' distributions: what it does, and why inputs and settings matter. Ecography 36(10):1058-1069

Mertzanis Y, Ioannis I, Mavridis A, Nikolaou O, Riegler S, Riegler A, Tragos A (2005) Movements, activity patterns and home range of a female brown bear (Ursus arctos, L.) in the Rodopi Mountain Range, Greece. Belgian J Zool 135(2):217-221

Mikoláš M, Tejkal M, Kuemmerle T, Griffiths P, Svoboda M, Hlásny T, Leitão PJ, Morrissey RC (2016) Forest management impacts on capercaillie (Tetrao urogallus) habitat 
distribution and connectivity in the Carpathians. Landsc Ecol 32(1):163-179

Millar CS, Blouin-Demers G (2012) Habitat suitability modelling for species at risk is sensitive to algorithm and scale: a case study of Blanding's turtle, Emydoidea blandingii, in Ontario, Canada. J Nat Conserv 20(1):18-29

Naidoo R, Kilian JW, Du Preez P, Beytell P, Aschenborn O, Taylor RD, Stuart-Hill G (2018) Evaluating the effectiveness of local- and regional-scale wildlife corridors using quantitative metrics of functional connectivity. Biol Conserv 217:96-103

Peters W, Hebblewhite M, Cavedon M, Pedrotti L, Mustoni A, Zibordi F, Groff C, Zanin M, Cagnacci F (2015) Resource selection and connectivity reveal conservation challenges for reintroduced brown bears in the Italian Alps. Biol Conserv 186:123-133

Phillips SJ, Dudík M (2008) Modeling of species distributions with Maxent: new extensions and a comprehensive evaluation. Ecography 31(2):161-175

Phillips SJ, Anderson RP, Schapire RE (2006) Maximum entropy modeling of species geographic distributions. Ecol Model 190:231-259

Phillips SJ, Dudík M, Elith J, Graham CH, Lehmann A, Leathwick J, Ferrier S (2009) Sample selection bias and presence-only distribution models: implications for background and pseudo-absence data. Ecol Appl 19(1):181-197

Polfus JL, Heinemeyer K, Hebblewhite M (2014) Comparing traditional ecological knowledge and western science woodland caribou habitat models. J Wildl Manag 78(1):112-121

Pop IM, Sallay A, Bereczky L, Chiriac S (2012) Land use and behavioral patterns of brown bears in the South-Eastern Romanian Carpathian mountains: a case study of relocated and rehabilitated individuals. Procedia Environ Sci 14:111-122

Pop IM, Bereczky L, Chiriac S, Iosif R (2018) Movement ecology of brown bears (Ursus arctos) in the Romanian Eastern Carpathians. Nat Conserv 26:15-31

Posillico M, Meriggi A, Pagnin E, Lovari S, Russo L (2004) A habitat model for brown bear conservation and land use planning in the central Apennines. Biol Conserv 118(2):141-150

Rastrelli G, O’Mahony K, Corradini A, Rizzardini G (2015) Livestock-large carnivore conflict in the Carpathian Mountains (Romania). WOLFLIFE Project (LIFE13NAT/ $\mathrm{RO} / 000205$ - Implementing best practices for the in-situ conservation of the species Canis lupus in the Eastern Carpathians'. International Zoological Congress of "Grigore Antipa" Museum

Rigg R, Adamec M (2007) Status, ecology and management of the brown bear (Ursus arctos) in Slovakia. Slovak Wildlife Society, Liptovský Hrádok, p 128

Roberge JM, Angelstam P (2004) Usefulness of the umbrella species concept as a conservation tool. Conserv Biol 18(1):76-85

Rode KD, Farley SD, Robbins CT (2006) Sexual dimorphism, reproductive strategy, and human activities determine resource use by brown bears. Ecology 87(10):2636-2646

Romportl D, Andreas M, Anděl P, Bláhová A, Bufka L, Gorčicová I, Hlaváč V, Mináriková T, Strnad M (2013)
Designing migration corridors for large mammals in the Czech Republic. J Landsc Ecol 6(1):47-62

Salvatori V (2004) Mapping conservation areas for large carnivores in the Carpathian Mountains. PhD. Thesis, University of Southampton, UK, p 231

Shepard ELC, Wilson RP, Rees WG, Grundy E, Lambertucci SA, Vosper SB (2013) Energy landscapes shape animal movement ecology. Am Nat 182(3):298-312

Soille P, Vogt P (2009) Morphological segmentation of binary patterns. Pattern Recogn Lett 30(4):456-459

Støen OG (2006) Natal dispersal and social organization in brown bears. PhD. Thesis, Norwegian University of Life Sciences, Aas, Norway, p 153

Swenson JE, Gerstl N, Dahle B, Zedrosser A (2000) Action plan for the conservation of the brown bear (Ursus arctos) in Europe. Council of Europe Publishing, Strasbourg Cedex

Swets JA (1988) Measuring the accuracy of diagnostic systems. Science 240(4857):1285-1293

Syfert MM, Smith MJ, Coomes DA (2013) The effects of sampling bias and model complexity on the predictive performance of MaxEnt species distribution models. PLoS ONE 8(2):1-9

van de Kerk M, Onorato DP, Criffield MA, Bolker BM, Augustine BC, Mckinley SA, Oli MK (2015) Hidden semiMarkov models reveal multiphasic movement of the endangered Florida panther. J Anim Ecol 84(2):576-585

Verma P, Raghubanshi A, Srivastava PK, Raghubanshi AS (2020) Appraisal of kappa-based metrics and disagreement indices of accuracy assessment for parametric and nonparametric techniques used in LULC classification and change detection. Model Earth Syst Environ 6(2):1045-1059

Vogt P, Riitters K (2017) GuidosToolbox: universal digital image object analysis. Eur J Remote Sens 50(1):352-361

Walther GR, Post E, Convey P, Menzel A, Parmesan C, Beebee TJC, Fromentin JM, Hoegh-Guldberg O, Bairlein F (2002) Ecological responses to recent climate change. Nature 416(6879):389-395

Webster R, Holt S, Avis C, Samec E, Sturm M (2001) The status of of the Carpathians: a report developed as part of the Carpathian ecoregion initiative. WWF International, Vienna

Wiegand T, Knauer F, Kaczensky P, Naves J (2004) Expansion of Brown Bears (Ursus arctos) into the Eastern Alps: a spatially explicit population model. Biodivers Conserv 13:79-114

Williams SH, Scriven SA, Burslem DFRP, Hill JK, Reynolds G, Agama AL, Kugan F, Maycock CR, Khoo E, Hastie AYL, Sugau JB, Nilus R, Pereira JT, Tsen SLT, Lee LY, Juiling S, Hodgson JA, Cole LES, Asner GP, Evans LJ, Brodie JF (2020) Incorporating connectivity into conservation planning for the optimal representation of multiple species and ecosystem services. Conserv Biol 34(4):934-942

Williamson MA, Creech TG, Carnwath G, Dixon B, Kelly V (2020) Incorporating wildlife connectivity into forest plan revision under the United States Forest Service's 2012 planning rule. Conserv Sci Pract 2(2):1-15

Zedrosser A, Støen OG, Sæbø S, Swenson JE (2007) Should I stay or should I go? Natal dispersal in the brown bear. Anim Behav 74(3):369-376 
Zeller KA, McGarigal K, Whiteley AR (2012) Estimating landscape resistance to movement: a review. Landsc Ecol 27(6):777-797

Zeller KA, Jennings MK, Vickers TW, Ernest HB, Cushman SA, Boyce WM (2018) Are all data types and connectivity models created equal? Validating common connectivity approaches with dispersal data. Divers Distrib 24(7):868-879

Zeller KA, Wattles DW, Conlee L, Destefano S (2019) Black bears alter movements in response to anthropogenic features with time of day and season. Mov Ecol 7(1):1-14
Ziółkowska E, Ostapowicz K, Radeloff VC, Kuemmerle T, Sergiel A, Zwijacz-Kozica T, Zięba F, Śmietana W, Selva $\mathrm{N}$ (2016) Assessing differences in connectivity based on habitat versus movement models for brown bears in the Carpathians. Landsc Ecol 31(8):1863-1882

Publisher's Note Springer Nature remains neutral with regard to jurisdictional claims in published maps and institutional affiliations. 